POLITYKA ENERGETYCZNA - ENERGY POLICY JOURNAL

$2019 \star$ Volume $22 \star$ Issue $4 \star 129-140$

DOI: $10.33223 / \mathrm{epj} / 114741$

\title{
The integration of energy and material recovery processes of municipal plastic waste into the national waste management system
}

ABSTRACT: In this study the current legal and market conditions of waste management in Poland are analyzed. The main legal basis for changes in the national municipal waste management system and their impact on the market situation in the last few years have been determined. Additionally, the important function of the selective collection and the key role of the separation of raw material fractions in waste sorting plants constituting the basis for the operation of Regional Municipal Waste Processing (RMWP) plants was underlined. Furthermore, the possibilities of developing electricity production technology in low and medium power modules using waste gasification techniques were emphasized. The stream of plastic mixture from municipal waste sorting was identified as problematic in the context of effective material recovery. Tests were conducted on the morphology of this waste stream from two sorting plants. In line with the literature data and as part of the analytical work, the properties of the plastic waste stream designated for recycling and the energy properties of the post-recycling plastic mixture were estimated. Tests results showed that the calorific value of this mixture reached $31.8 \mathrm{MJ} / \mathrm{kg}$, whereas, ash and chlorine content equaled $2.7 \%$ and $1.1 \%$ of dry

Corresponding Author: Arkadiusz Primus; e-mail: arkadiusz.primus@investeko.pl

1 R\&D Departament, R\&D Center INVESTEKO SA, Poland; e-mail: arkadiusz.primus@investeko.pl

2 Waste Management Departament, Institute of Environmental Engineering, Poland; ORCID iD: 0000-0003-26985437; e-mail: czeslawa.rosik-dulewska@ipis.zabrze.pl

2019. The Author(s). This is an open-access article distributed under the terms of the Creative Commons Attribution-ShareAlike International License (CC BY-SA 4.0, http://creativecommons.org/licenses/by-sa/4.0/), which permits use, distribution, and reproduction in any medium, provided that the Article is properly cited. 
mass, respectively. These parameters indicate that the mixture as a high-calorific fuel component may be a valuable addition to refuse-derived fuel (RDF) produced from the over-sieve fraction of municipal waste. Concurrently, as a result of the development of waste gasification technologies with a high share of electricity production in low-medium power range plants, it is possible to integrate them with plastic recycling and RMWP plants in the Polish national waste management system.

KEYWORDS: waste fuel properties, waste gasification, cogeneration, waste energy, waste morphology

\section{Introduction}

The Polish national waste management system has been functioning for several years relying on the operation of Regional Municipal Waste Processing (RMWP) plants, where separation processes of waste designated for further treatment are carried out.

This system is a good basis for the implementation of specialized technologies for the management of individual waste streams using, first and foremost, recycling and material recovery technologies, followed by the energy conversion of residual fractions.

The criteria for determining the development trend of the municipal waste management model should be the principle of proximity and systemic increase of the technical potential of waste management or waste processing at the place of origin.

Plastics are the main fraction separated from mixed municipal waste and selectively collected waste, which are separated in the sorting plants into fractions intended for further treatment in recycling plants.

In this situation, it is necessary to expand mechanical-biological treatment (MBT) plants by using technological modules that would facilitate recycling processes for the separated waste fractions and thermal treatment of residual fractions from the processing of plastics with high energy potential.

The development of waste gasification technology and energy production with a high share of electricity production in low-medium power range modules is currently visible. Therefore, integrating plastic recycling technologies and modular thermal treatment installations for residual fractions, which are the main reason for the expansion of the existing municipal plants relying on mechanical sorting facilities, amy be considered. 


\section{Market conditions of waste management in Poland}

Municipal waste management is currently in a phase of dynamic development and at the same time faces serious challenges that result from the successive introduction of circular economy principles.

In the last few years, the national waste management has undergone significant system and technological transformations, including the transfer of responsibility to local governments, which, in return, stabilized the transport system and concentration of waste streams regionally in RMWP plants, among others, thanks to technical standardization of sorting plants. Currently, over 120 plants designated for sorting municipal waste operate in Poland, which justifies the planning of further development of the system based on mechanical-biological treatment processes.

An important legal event for the current situation was the introduction of a ban on the landfilling of waste with fuel properties, i.e. CV above $6 \mathrm{MJ} / \mathrm{kg}$, which should urge the construction of regional thermal waste treatment plants, as there is currently a significant deficit in such plants.

According to literature sources, the estimated amount of the over-sieve fraction (separated in MBT plants) ranges from $30-45 \%$ of the mixed municipal waste stream entering the RMWP plants (Ściążko and Nowak 2017). At the same time, from the balance sheet calculations based on the Polish National Waste Management Plan (PNWMP) and own surveys carried out in 12 RMWP plants, it is estimated that this share is about $50 \%$, which means that the stream intended for thermal treatment is about 4 million tons/year (Primus and Rosik-Dulewska 2018) whereas, the current demand is approx. 2 million tons/year.

Another significant factor affecting the waste management sector is the over $100 \%$ increase in the marshal's fee for waste storage, which causes successively higher prices of waste management, and therefore should enforce the market profitability of recycling and waste recovery processes.

From the legislative point of view, the EU and national legal regulations oblige an increase in the role of material recovery and recycling processes in the waste management system in line with the circular economy framework. One of the requirements to be achieved in the current PNWMP (2016-2022) is material recovery and recycling up to 50\% from the municipal waste stream.

Simultaneously, attention should be paid to new, strict environmental safety requirements for waste treatment installations and increased standards for the transparency of waste flow on the market, which are the result of changes in regulations that took place in 2018 and 2019 (i.e. amendments to the Act on Waste and the Act on Maintaining Cleanliness and Order in $\mathrm{Mu}-$ nicipalities). The consequence of all these changes in legal regulations is a significant increase in the cost of waste treatment, and a more visible lack of local and regional waste treatment infrastructure that meets stringent technical and environmental requirements.

Due to the inability to landfill waste with fuel properties $(\mathrm{CV}>6 \mathrm{MJ} / \mathrm{kg})$, there is a growing problem with the ballast fraction produced in MBT plants, which is a post-sorting fraction. Sim- 
ilar difficulties also arise in the management of separated material fractions, especially plastics, due to their heterogeneous quality, which is an important market criterion for their real material recovery.

These conditions imply that the process of separating plastics together with their division into types is technical and cost-intensive, thus limiting the separation process to basic streams such as polyethylene terephthalate (PET) or low-density polyethylene (LDPE). Other types of plastics, due to their quality dispersion and irregular presence in the waste stream, are not separated and remain in the stream of the plastic mixture. The diagram illustrating the emplacement of the plastic stream fraction in the MPT plants is shown in Figure 1.

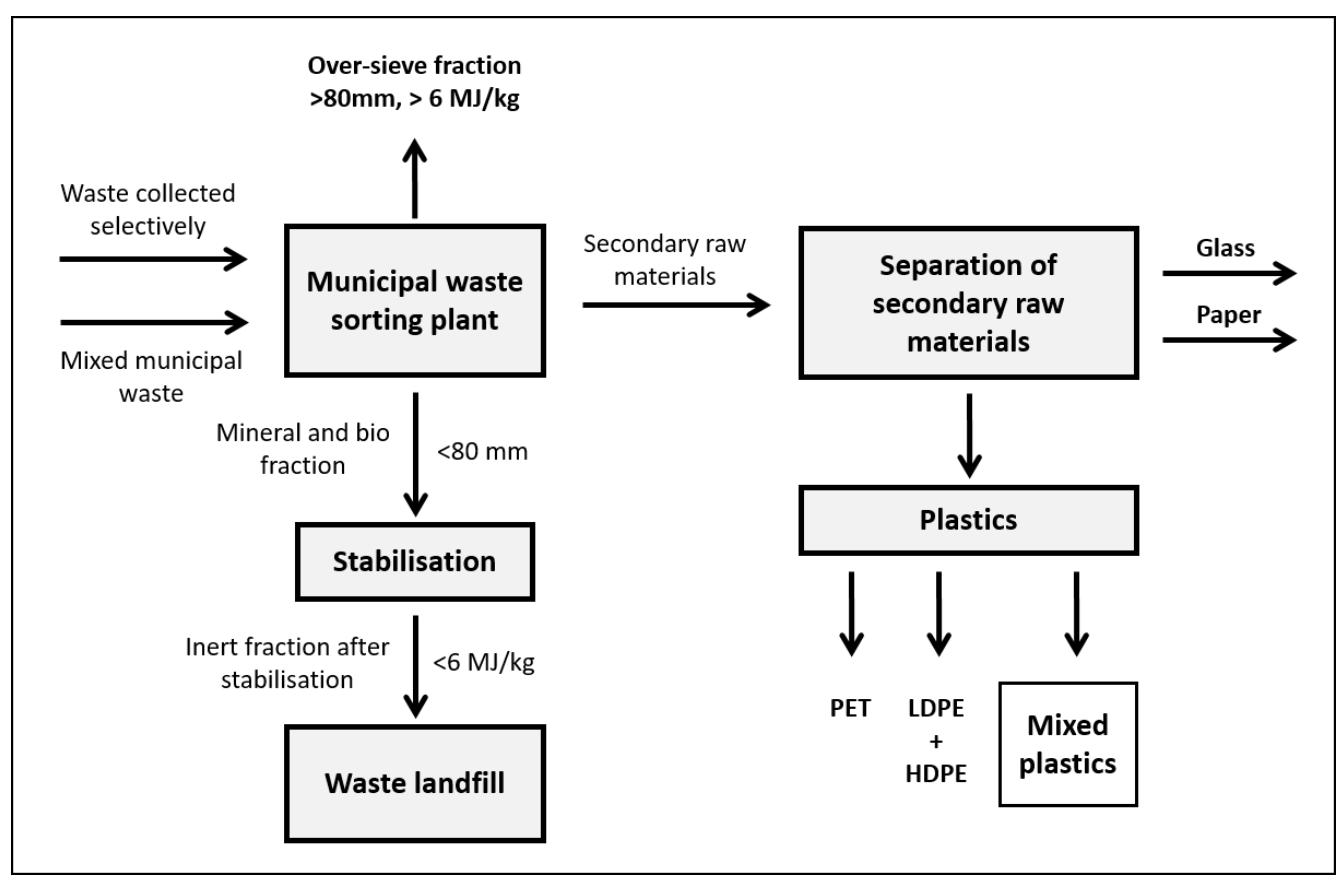

Fig. 1. Emplacement of the plastic stream fraction in the MBT plant Own elaboration

Rys. 1. Umiejscowienie frakcji tworzyw wtórnych w instalacji MBP

At present, the plastic mixture stream poses not only an environmental problem, but also an economic one, due to the difficulties associated with its technical processing into semi-finished products or raw material substitutes, which would allow the process to be qualified as recycling or material recovery.

Thus, in order to increase the pro-environmental effectiveness of the mechanical-biological treatment process, it is necessary to properly recognize the residual stream of the above mentioned plastic mixture and optimal selection of processing techniques for recycling and thermal treatment. 


\section{Tests and characteristics of plastic waste fractions}

In the selective collection of the municipal waste and in sorting plants, plastic waste streams are usually segregated into easily identifiable and easily separated types, which include: PET (bottles are sorted into different colors), PE (LDPE foil) and PE (household chemicals HDPE bottles) intended directly for recycling. In addition, is separated a stream of undefined and hard plastics forming a mixture of various types of waste, which is heterogeneous and is not yet well recognized, but accounts for $20-30 \%$ of the stream in question.

The study presents the test results on the above mentioned fraction. Tests were carried out to determine its recycling/thermal conversion capacity. The main goal was therefore to approximate not only its qualitative but also its quantitative share. Samples were taken in August 2019 from two independent sorting plants located in urban areas (mostly multi-family and mixed-housing neighborhoods). In these areas, selective waste collection is implemented and the technical requirements for the RMWP plant are met.

The scope for qualitative/quantitative tests was defined by taking future management trends of this stream in recycling and energy recovery plants into account. Waste morphology tests were conducted on the following plastic fraction types:

$\downarrow$ Polyethylene terephthalate (PET),

$\checkmark$ Polyethylene (PE) - high and low density (HDPE and LDPE),

$\checkmark$ Polyvinyl chloride (PVC),

$\checkmark$ Polypropylene (PP),

$\downarrow$ Polystyrene (PS),

$\diamond$ Other.

Other plastic fractions used in packaging industry and everyday use which occur in the municipal waste stream include: Terpolymer, Acrylonitrile-Butadiene-Styrene (ABS), Polymethyl Methacrylate (PMMA), Polycarbonate (PC), Polyamide (PA), Polytetrafluoroethylene (PTFE), Polyurethanes (PU), silicones and others in trace amounts.

Sampling and testing methodology for determining the morphological composition, was elaborated in accordance with the standards transferring the PN-EN 15442:2011 standard on Solid recovered fuels, PN-EN 154432011 Solid secondary fuels - Methods for the preparation of the laboratory sample and also Methods for sampling indicated in the Regulation of the Minister of the Environment of June 8, 2016 on the specific technical conditions for qualifying part of energy recovered from thermal treatment of municipal waste (Journal of Laws 2016, item 847).

Samples were taken from the MPGK plant in Świętochłowice and KOMART in Knurów, in amounts of 2,740 kg and 1,850 kg, respectively. The samples were transported to the INVESTEKO SA R\&D Centre in Świętochłowice, where operates a plastic recycling installation, which has a permit for waste material recovery using the R3 method. Three representative samples were extracted from each transport $-20 \mathrm{~kg}$ on average, and morphological tests were performed on each of them (Table 1). 
TABLE 1. Share of selected polymer fractions in the residual stream of plastic waste

TABELA 1. Udział wybranych frakcji polimerowych w strumieniu frakcji resztkowej odpadów z tworzyw sztucznych

\begin{tabular}{|c|c|c|c|c|c|c|c|c|c|c|}
\hline \multirow{3}{*}{ No } & \multirow{2}{*}{ Sample } & \multicolumn{4}{|c|}{ MPGK Świętochłowice } & \multicolumn{4}{|c|}{ Komart Knurów } & \multirow{3}{*}{$\begin{array}{c}\text { Total } \\
\text { average } \\
{[\%]}\end{array}$} \\
\hline & & I & II & III & average & I & II & III & average & \\
\hline & type of material & \multicolumn{4}{|c|}{ weight share [\%] } & \multicolumn{4}{|c|}{ weight share [\%] } & \\
\hline 1 & PET & 0.3 & 0.2 & 0.8 & 0.43 & 0.3 & 0.3 & 1.4 & 0.67 & 0.55 \\
\hline 2 & $\mathrm{PE}$ & 14.7 & 11.3 & 9.8 & 11.93 & 16.8 & 13.9 & 11.5 & 14.07 & 13.00 \\
\hline 3 & PCV & 2.4 & 3.1 & 4.4 & 3.30 & 2.4 & 3 & 2.8 & 2.73 & 3.02 \\
\hline 4 & PP & 76.4 & 80.2 & 79.2 & 78.60 & 72.2 & 77.8 & 78.3 & 76.10 & 77.35 \\
\hline 5 & PS & 1.8 & 1.3 & 1.5 & 1.53 & 3.9 & 1.2 & 1.3 & 2.13 & 1.83 \\
\hline 6 & Other plastics & 3.5 & 3.6 & 3.5 & 3.53 & 4.1 & 3.5 & 4.6 & 4.07 & 3.80 \\
\hline 7 & Other non-plastics & 0.9 & 0.3 & 0.8 & 0.67 & 0.3 & 0.3 & 0.1 & 0.23 & 0.45 \\
\hline
\end{tabular}

The extraction of individual material fractions was carried out based on the standards: PN-EN ISO 1043-1: 2004 and PN-EN ISO 11469: 2003 (visual and organoleptic assessment of the material). Assessment and identification of PE, PP and PS (according to the above-mentioned standards) was made based on criteria such as: material form and mechanical properties and their characteristics, i.e. color, transparency, surface, hardness (surface roughness), deformability and dropping sound.

Furthermore, a flame test was conducted to assess and identify individual materials according to the following characteristics: flame behavior, flame appearance, odor after sample quenching, which are accurately determined for many materials. The application of this test enables high accuracy identification of materials less frequently used and occurring in smaller quantities in the municipal waste stream. Such materials could be the following: PC, PA, PMMA, PU or silicones.

The applied test methodology allowed the composition of the plastic stream and the separation of polymers due to their potential and fuel properties to be determined. Morphology test results of plastics are presented in Table 1 .

The conducted research shows that, the real (technical and market) share of plastics intended for recycling in the residual fraction stream of plastics is PP and PE (HDPE). These waste types in recycling plants are subjected to the following mechanical processing procedures:

- grinding into 20-40 mm fraction (depending on market requirements),

$\checkmark$ cleaning and standardization of the PE+PP stream through hydrostatic separation and washing in a flow tank fed with aqueous solutions,

$\checkmark$ separation of water from the PE+PP stream intended for material processing using vortex techniques and heating system (drying in a flow of hot air),

$\checkmark$ heat treatment of $\mathrm{PE}+\mathrm{PP}$ stream in liquefaction and plastic extrusion processes, and production of regranulates as market products,

The process of hydrostatic separation of plastics consists in using the difference in the specific gravity (SG) of individual plastics. The $\mathrm{PE}+\mathrm{PP}$ mixture has a specific gravity $<1 \mathrm{~kg} / \mathrm{m}^{3}$, which causes plastic flakes to float on the surface, separating them from the mixture of other plastic 
streams characterized by a higher SG than water. In this way, the standardization of the PE+PP stream is relatively easy from the technical point of view and relatively low cost.

It should be noted that, the vast variety of applications, mainly PP and adaptation of their mechanical properties to different tasks, necessitate the use of technical additives such as dyes, reinforcing fillers (e.g. talc) and others. These types of additives when used in the plastic industry often cause an increase in their specific gravity and consequently a decrease in the stream of $\mathrm{PE}+\mathrm{PP}$ mixture subjected to hydrostatic separation process. As a result, there is a quantity increment of the residual mixture intended to be used as a high-calorific fuel and enriching component for the RDF (Refuse Derived Fuel).

In order to identify the average proportion of plastic stream with specific gravity greater than $1 \mathrm{~kg} / \mathrm{m}^{3}$, additional tests were conducted. For this purpose, the plastic recycling plant located at INVESTEKO SA R\&D Centre in Świętochłowice was equipped with a sink/float tank intended for the separation and washing of mixed plastic streams coming from the municipal waste sorting plant.

Tests showed that the share of the residual mixture after hydrostatic standardization is $25-30 \%$ of the input stream, containing the complete morphological composition of the primary mixture.

Due to the concentration of heavy plastics in the residual mixture stream, the study indicated the need for additional technological solutions when dealing with PVC separation from the residual plastic fraction stream. This would ensure the required standardization and prevent high chlorine concentrations.

On the other hand, in order to reduce the chlorine content in the high-energy residual mixture, the mechanical treatment process in the recycling plants should be preceded by technical separation of PVC using optical detection technology (based on infrared light absorption). The residual mixture will eventually constitute the fuel component, thus, enriching the RDF stream. Currently used techniques of optical separation of the selected mixture component with its low mass share allow for high efficiency $(80-90 \%)$, which ultimately contributes to the chlorine content reduction in the fuel component to a value close to $1 \%$.

Types of residual plastic mixture streams obtained from processing in a plastic recycling plant and their designation for further use is shown in Table 2.

TABLE 2. Division and designation of the plastic mixture streams obtained from the sorting process

TABELA 2. Podział i przeznaczenie strumieni mieszaniny odpadowych tworzyw sztucznych uzyskanych $\mathrm{w}$ procesie sortowania

\begin{tabular}{|l|c|l|}
\hline \multicolumn{1}{|c|}{ Type of plastic/material } & Mass share [\%] & \multicolumn{1}{c|}{ Designation } \\
\hline PE/PP mixture & 73 & $\begin{array}{l}\text { Recycling } \\
\text { Regranulate production }\end{array}$ \\
\hline Residual plastic mixture & 24 & $\begin{array}{l}\text { High calorie fuel component. } \\
\text { Standardization of fuels from RDF waste }\end{array}$ \\
\hline PVC & 3 & $\begin{array}{l}\text { Mechanical separation and recovery other than } \\
\text { PE-PP recycling plant }\end{array}$ \\
\hline Remainder & $<1$ & Disposal \\
\hline
\end{tabular}




\section{Function integration of recycling and energy recovery from waste}

The literature on the subject indicates that, there are diverse fuel properties of plastics recovered from municipal waste (Table 3 ).

TABLE 3. List of basic plastic fuel parameters from municipal waste

TABELA 3. Zestawienie podstawowych parametrów paliwowych tworzyw sztucznych pochodzących z odpadów komunalnych

\begin{tabular}{|c|c|c|c|c|}
\hline No & Type of Plastic & $\begin{array}{c}\text { Calorific Value } \\
{[\mathrm{MJ} / \mathrm{kg}]}\end{array}$ & $\begin{array}{c}\text { Ash Content } \\
{[\% \mathrm{DM}]}\end{array}$ & $\begin{array}{c}\text { Chlorine Content } \\
{[\% \mathrm{DM}]}\end{array}$ \\
\hline 1 & PET & 21.81 & 2.15 & 1.43 \\
\hline 2 & PE & 41.80 & 2.39 & 0.97 \\
\hline 3 & PCV & 13.69 & 7.94 & 4.43 \\
\hline 4 & PP & 30.90 & 2.93 & 1.24 \\
\hline 5 & PS & 38.97 & 1.38 & 0.16 \\
\hline
\end{tabular}

Source: Wasilewski and Siudyga 2013.

The above table shows that, the calorific value (except PVC) falls within a wide range $(21.81-41.80 \mathrm{MJ} / \mathrm{kg})$. Ash content also vary i.e. from $1.38-2.93 \%$ of dry mass, whereas chlorine content between $0.16-1.43 \%$ of dry mass, and it is worth noting that PET and PP have a relatively high content of chlorine $1.43 \%$ and $1.24 \%$ respectively.

The tests conducted to date on the stream of plastic mixtures coming from selective collection of waste (Hryb 2018) also indicate good and valuable fuel parameters, characterized by an average calorific value of $27.2 \mathrm{MJ} / \mathrm{kg}$, ash content $5.51 \%$ of dry mass, whereas chlorine at $1.44 \%$ of dry mass.

Based on the above tests and calculations were determined the morphological composition and basic fuel characteristics of the high-calorie fuel component. These values were adopted for the theoretical determination of the basic fuel properties, enabling to obtain an average calorific value of $30 \mathrm{MJ} / \mathrm{kg}$ for other plastics (i.e. ABS, PC, PMMA) as well as ash and chlorine content $2 \%$ and $1 \%$ of dry mass respectively. The results of these calculations are presented in Table 4 .

The determined parameters of the high-calorie fuel component from the mixture of recycled plastics support the possibility of using it as an enriching and stabilizing additive for the production of RDF based on the over-sieve fraction of municipal waste.

Having an increased calorific value of $15-17 \mathrm{MJ} / \mathrm{kg}$, lower ash content and controlled stable chlorine content makes this fuel stream a decent feedstock to low power waste treatment plants based on gasification technology and CHP with a high-efficiency cogeneration system (Primus 
TABLE 4. Qualitative characteristics of the high-calorie plastic fuel component

TABELA 4. Charakterystyka jakościowa wysokokalorycznego komponentu paliwowego z tworzyw sztucznych

\begin{tabular}{|c|c|c|c|c|c|}
\hline No & Type of Plastic & $\begin{array}{c}\text { Weight share } \\
{[\%]}\end{array}$ & $\begin{array}{c}\text { Calorific Value } \\
{[\mathrm{MJ} / \mathrm{kg}]}\end{array}$ & $\begin{array}{c}\text { Ash Content } \\
{[\% \mathrm{DM}]}\end{array}$ & $\begin{array}{c}\text { Chlorine Content } \\
{[\% \mathrm{DM}]}\end{array}$ \\
\hline 1 & PP & 63.8 & \multirow{6}{*}{31,8} & \multirow{6}{*}{2,7} & \multirow{6}{*}{1,1} \\
\hline 2 & PE & 8.2 & & & \\
\hline 3 & PS & 8.2 & & & \\
\hline 4 & PET & 2.5 & & & \\
\hline 5 & PVC & 1.8 & & & \\
\hline 6 & Other & 15.5 & & & \\
\hline
\end{tabular}

Based on estimated calculations.

and Rosik-Dulewska 2017). Such a system ensures a higher power to heat ratio i.e. above 0.7, which translates into a favorable share of electricity vs heat in CHP systems in comparison to similar power systems based on gas turbines or steam turbines for which the ratio rarely exceeds 0.4 (Skorek and Kalina 2005).

The production of high quality RDF enriched with a stabilizing addition of a fuel component from a mixture of plastics can be the basis for joining and integrating low-power gasification installation, plastic recycling facility and RMWP plant equipped with a sorting line. The schematic diagram of the installation integration is shown in Figure 2.

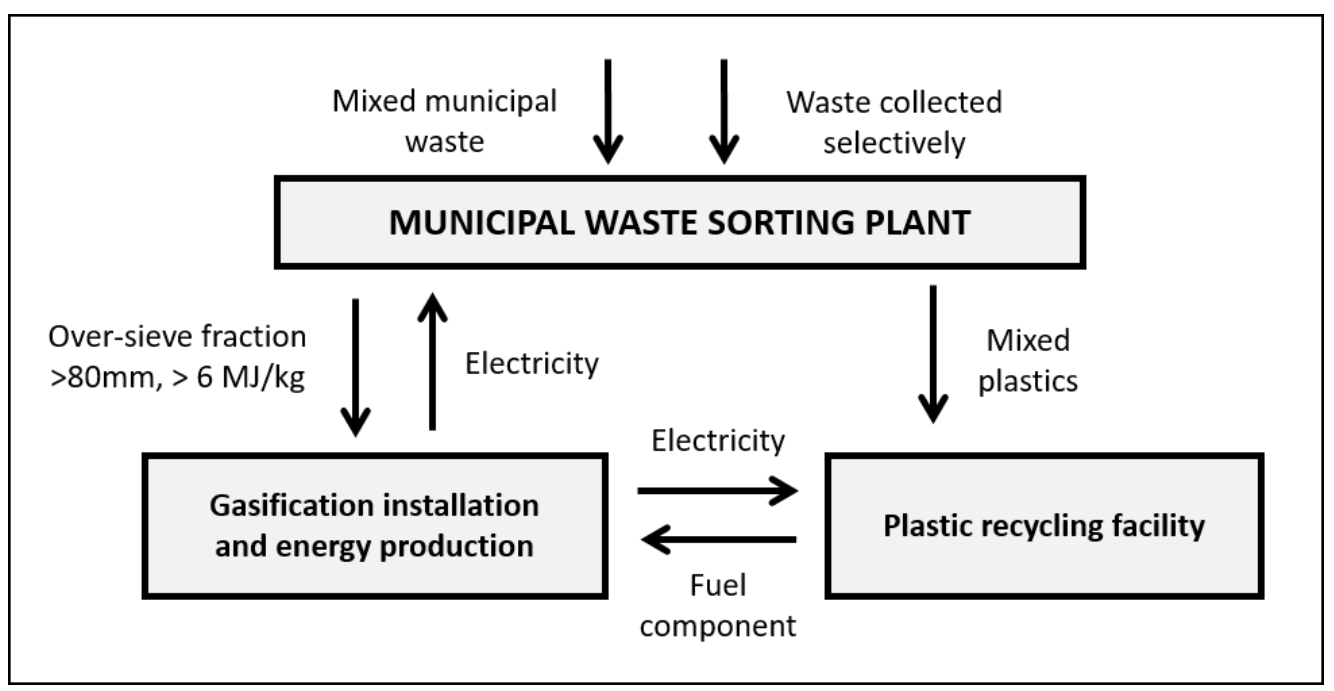

Fig. 2. Integrated system of recycling processes and energy recovery in the MBT model (own elaboration)

Rys. 2. Zintegrowany system procesów recyklingu i odzysku energii w modelu MBP 
The proposed integration of processes in ecological and economical terms will allow for an efficient use of residual fuel streams coming from the sorting process. Moreover, this will reduce the unit costs of waste processing by limiting their transport costs to distant plants. In addition, this will allow the use of produced electricity for their own needs, thus limiting the costs of electricity distribution to the required minimum.

Such an integrated system of recycling, gasification and cogeneration in conjunction with the RMWP plant will significantly increase the eco-efficiency of the waste management system, and at the same time be in line with the circular economy assumptions.

\section{Summary}

The Polish national waste management model is currently in a phase of significant and dynamic changes that have been forced by the introduction of new legal regulations in the last few years. The consequence of these changes can be observed in the increase of municipal waste treatment costs. Changing market conditions increase the profitability of waste recovery-oriented processes. The development of cost-effective waste management systems based primarily on material and energy recovery processes is gaining importance. Effective separation of raw material waste streams "at the source" and mechanical separation in waste sorting plants is an important element of the system that also allows for the development of the plastics recycling sector.

The morphology of the plastic mixture coming from the municipal waste sorting plant is characterized by heterogeneity, which translates into a decrease in the efficiency of recycling processes. Morphological tests of the residual stream of recycled plastics indicate good energy properties. Therefore, the technical possibilities of integrating recycling technologies and energy conversion of residual plastic waste appear to be crucial in ensuring efficiency increase of these processes in the national waste management system. This, in return, will guarantee its development towards the circular economy.

\section{References}

ACT on waste of 14 December 2012, Journal of Laws of 2016, Item 1987 (Ustawa o porzadku i czystości w gminie, Dz.U. 1996, Nr 132, poz. 622, tekst jedn. z. Dz.U. z 2018, poz. 1454) (in Polish).

$\mathrm{ACT}$ on Waste and the Act on Maintaining Cleanliness and Order in Municipalities, Journal of Laws of 1996, No. 132, item 622, Journal of Laws of 2018, Item 1454 (Ustawa o porządku i czystości w gminie, Dz.U. 1996, Nr 132, poz. 622, tekst jedn. z. Dz.U. z 2018, poz. 1454) (in Polish).

Commission Implementing Decision (EU) 2018/1147 of 10 August 2018 establishing best available techniques (BAT) conclusions for waste treatment, under Directive 2010/75/EU of the European Parliament 
and of the Council (Decyzja Wykonawcza Komisji (UE) 2018/1147 z dnia 10 sierpnia 2018 r. ustanawiająca konkluzje dotyczace najlepszych dostępnych technik (BAT) w odniesieniu do przetwarzania odpadów zgodnie z dyrektywa Parlamentu Europejskiego i Rady 2010/75/UE) (in Polish).

Directive 2010/75/EU of the European Parliament and of the Council of 24 November 2010 on industrial emissions (Dyrektywa Parlamentu Europejskiego nr 2010/75/UE z dnia 24 listopada 2010 r. w sprawie emisji przemystowych) (in Polish).

HRYB, W. 2019. Residues from sorting plastics as a component of fuels from waste (Pozostalości z sortowania tworzyw sztucznych jako sktadnik paliw z odpadów). Przemyst Chemiczny Vol. 98, No. 1 (in Polish).

NWMP 2022; National Waste Management Plan 2022 (M.P. of 2016, item 784) (KPGO 2022; Krajowy Plan Gospodarki odpadami 2022 (M.P. z 2016, poz. 784)) (in Polish).

PN-EN 15442: 2011 Solid secondary fuels - Sampling methods (PN-EN 15442: 2011, State paliwa wtórne-Metody pobierania prób) (in Polish).

PN-EN 15443: 2011 Solid secondary fuels - Methods for preparing a laboratory sample (PN-EN 15443: 2011, State paliwa wtórne - Metody przygotowywania próbki laboratoryjnej) (in Polish).

PRIMUS, A. and RosiK-DULEWSKA, C. 2017. Production of energy in low-power cogeneration sources using municipal waste gasification technology. Legal and economic conditions (Produkcja energii w źródtach kogeneracyjnych małej mocy z wykorzystaniem technologii zgazowania odpadów pochodzenia komunalnego. Uwarunkowania prawne i ekonomiczne). Polityka Energetyczna - Energy Policy Journal Vol. 20, Iss. 3, pp. 79-92 (in Polish).

Primus, A. and RosiK-DULEWSKA, C. 2018. Fuel potential of the over-sieve fraction of municipal waste and its role in the national waste management model (Potencjat paliwowy frakcji nadsitowej odpadów komunalnych i jego rola w krajowym modelu gospodarki odpadami). Zeszyty Naukowe Instytutu Gospodarki Surowcami Mineralnymi i Energia Polskiej Akademii Nauk No. 105, pp. 121-134 (in Polish).

Regulation of the Minister of Environment, on mechanical and biological treatment of mixed municipal waste, of 11 September 2012, Journal of Laws of 2012, Item 1052 (Rozporzadzenie Ministra Środowiska z dnia 11 września 2012 r. w sprawie mechaniczno-biologicznego przetwarzania zmieszanych odpadów komunalnych, Dz.U. 2012, poz. 1052) (in Polish).

Regulation of the Minister of Economy of 16 July 2015 on the acceptance of waste for landfill. Journal of Laws 2015 No. 0, Item 1277 (Rozporzadzenie Ministra Gospodarki z dnia 16 lipca 2015 r. w sprawie dopuszczania odpadów do składowania na składowiskach, Dz.U. z 2015, poz. 1277) (in Polish).

Regulation of the Minister of the Environment of 8 June 2016, on the technical conditions for qualifying a part of the energy recovered from thermal treatment of waste, Journal of Laws 2016, Item 847 (Rozporządzenie Ministra Środowiska z dnia 8 czerwca 2016 r. w sprawie warunków technicznych kwalifikowania części energii odzyskanej z termicznego przekształcania odpadów, Dz.U. 2016, poz. 847) (in Polish).

SKOREK, J. and KALINA, J. 2005. Gas cogeneration systems (Gazowe układy kogeneracyjne). Scientific and Technical Publishing House; Warsaw (in Polish).

ŚCIĄŻKO M. and NOWAK, W. 2017. Technologies for gasification of municipal waste (Technologie zgazowania odpadów komunalnych). Nowa Energia 1, pp. 22-26 (in Polish).

WASILEWSKI, R. and SIUDYGA, T. 2013. Energy recovery of plastic waste (Odzysk energetyczny odpadowych tworzyw sztucznych). Chemik No. 5, Vol. 67, pp. 840-851 (in Polish). 


\section{Integracja procesów odzysku/przekształcenia energetycznego i materiałowego odpadów tworzyw sztucznych pochodzenia komunalnego w krajowym systemie gospodarki odpadami}

\section{Streszczenie}

W artykule przeanalizowano obecne uwarunkowania prawno-rynkowe gospodarki odpadami w Polsce. Określono główne podstawy prawne zmian w krajowym systemie gospodarki odpadami komunalnymi i ich wpływ na sytuację rynkową w ostatnich kilku latach. Wskazano istotną funkcję selektywnej zbiórki i kluczową rolę separacji frakcji surowcowych w sortowni odpadów stanowiących podstawę działania Regionalnych Instalacji Przetwarzania Odpadów Komunalnych. Jednocześnie podkreślono możliwości rozwoju technologii produkcji energii elektrycznej w modułach małej i średniej mocy z wykorzystaniem technik zgazowania odpadów. Autorzy wskazali strumień mieszaniny tworzyw sztucznych z sortowania odpadów komunalnych jako problematyczny w kontekście efektywnego odzysku materiałowego. Przeprowadzili badania $\mathrm{w}$ zakresie morfologii tego strumienia odpadów $\mathrm{z}$ dwóch sortowni. W ramach prac analitycznych, bazując jednocześnie na danych literaturowych, dokonano oszacowania właściwości tego strumienia z przeznaczeniem do recyklingu oraz właściwości energetycznych mieszaniny tworzyw sztucznych pozostałych po procesie recyklingu. Badania i obliczenia wykazały, że wartość opałowa tej mieszaniny może kształtować się na poziomie $31,8 \mathrm{MJ} / \mathrm{kg}$, a zawartość popiołu i chloru odpowiednio na poziomach 2,7 i 1,1\%. Parametry te wskazują, że mieszanina, jako wysokokaloryczny komponent paliwowy, może stanowić wartościowy dodatek do paliw RDF (Refuse Derived Fuel - paliwo z odpadów) produkowanych z frakcji nadsitowej odpadów komunalnych. Jednocześnie z uwagi na rozwój technologii zgazowania odpadów z wysokim udziałem produkcji energii elektrycznej w instalacjach małej i średniej mocy możliwa jest ich integracja $\mathrm{z}$ instalacjami recyklingu tworzyw sztucznych oraz RIPOK w krajowym systemie gospodarki odpadami.

SŁOWA KLUCZOWE: właściwości paliwowe odpadów, zgazowanie odpadów, kogeneracja, energia z odpadów, morfologia odpadów 